\title{
Perancangan Game OTW SARJANA Menggunakan Metode Forward Chaining
}

\author{
Muhammad Bambang Firdaus ${ }^{1 *}$, Damar Sanggara Habibie ${ }^{2}$, Fadli Suandi ${ }^{3}$, \\ M Khairul Anam ${ }^{4}$, Lathifah ${ }^{5}$ \\ 1'bambangf@fkti.unmul.ac.id, ${ }^{2}$ habibiedamar@gmail.com, ${ }^{3}$ fadli.suandi@polibatam.ac.id, \\ ${ }^{4}$ khairulanam@sar.ac.id, ${ }^{5}$ lathifah@teknokrat.ac.id \\ ${ }^{1,2}$ Informatika, Universitas Mulawarman \\ ${ }^{3}$ Teknik Multimedia \& Jaringan,Politeknik Negeri Batam \\ ${ }^{4}$ Teknologi Informasi, STMIK Amik Riau \\ ${ }^{5}$ Informatika, Universitas Teknokrat
}

\begin{abstract}
Abstrak
Perancangan game ini bertujuan untuk memberikan gambaran perkuliahan kepada siapapun yang memainkannya. Data yang digunakan pada game ini berdasar pada pengalaman penulis yang secara langsung terlibat perkuliahan di Informatika Universitas Mulawarman. Tahapan-tahapan dalam pembuatan game ini adalah konsep, desain, pembuatan game dan pengujian. Konsep dasar dalam pembuatan game ini adalah tentang siswa Sekolah Menegah Atas yang akan melanjutkan pendidikannya ke tingkat perkuliahan, oleh karena itu game ini didesain memiliki mekanisme yang semirip mungkin dengan syarat-syarat perkuliahan pada Informatika Universitas Mulawarman. Metode yang digunakan pada game ini adalah metode Forward Chaining yang digunakan pada saat pemain akan naik ke semester (level) selanjutnya dan untuk menentukan nilai pada setiap semester (level) tersebut. Hasil yang didapatkan dari pengujian Black Box adalah semua sistem berjalan dengan baik dari sisi tampilan, desain, permainan, dan metode Forward Chaining.
\end{abstract}

Kata kunci: Perkuliahan, Metode Forward Chaining, Desain, Semester, Black Box

The design of this game aims to provide an overview of lectures to anyone who plays it. The data used in this game is based on the experience of the author who was directly involved in lectures at Mulawarman University Informatics. The stages in making this game are Concept, Design, Game Development and testing. The basic concept in making this game is about high school students who will continue their education to the lecture level, therefore this game is designed to have a mechanism that is as similar as possible to the requirements of lectures at Mulawarman University Informatics. The method used in this game is the Forward Chaining method which is used when the player will move up to the next semester (level) and to determine the value in each semester (level). The results obtained from the Black Box testing are that all systems run well in terms of appearance, design, gameplay, and the Forward Chaining method.

Keywords: Lectures, forward chaining method, Design, Semester, Black Box

\section{Pendahuluan}

Hiburan yang bisa dilakukan oleh komputer salah satunya adalah bermain Game. Game bisa dimainkan di berbagai platform dengan kelebihan dan kekurangannya masing-masing, PC Games adalah game yang bisa dimainkan di komputer sedangkan Console Games bisa dimainkan di console seperti Playstation, Xbox, Nintendo Switch dan lainnya lalu ada pula mobile games yaitu game yang bisa dimainkan di platform mobile seperti Smartphone dan Tablet [1].

Satu dari sekian banyak program yang bisa di operasikan pada perangkat berbasis komputer ialah program game [2]. Pengguna dapat dengan fleksibel mendapatkan game untuk dimainkan pada komputer atau smartphone [3]. Secara umum game terbagi pada dua jenis, yang pertama adalah game offline dan yang kedua adalah game online [4][5]. Game offline adalah game yang bisa digunakan pada komputer atau smartphone tanpa harus terhubung ke internet [6][7]. Hal tersebut dimungkinkan untuk dilakukan karena semua perintah dan data game sudah terpasang dan tersimpan di dalam komputer [8]. Sedangkan game online ini secara teknis terpusat pada suatu server. Sehingga untuk menjalankannya dibutuhkan akses ke server melalui jaringan internet [9]. 
Jurnal Sistem Informasi dan Sistem Komputer, Vol.6, No.2, Juli 2021

ISSN: 2715-906X (Online)

d 0 i $10.51717 /$ simkom.v6i2.56

Game ini mengangkat cerita tentang perkuliahan karena saat seorang mahasiswa berkuliah maka mahasiswa tersebut harus melalui banyak rintangan dan hadangan di depannya, namun harus tetap fokus pada beberapa tujuan-tujuan utamanya. Tujuannya meliputi ilmu-ilmu terapan yang didapatkan selama berkuliah dan mendapatkan nilai yang terbaik dari mata kuliah yang dijalani, karena itu penulis berharap dapat melakukan hal yang sama penelitian ini. Pada penelitian ini pemain game diwajibkan tetap fokus untuk memperhatikan materi secara terstruktur, dengan melewati beragam rintangan dan hadangan menanti di selama waktu yang telah ditentukan pada masing-masing level. Sebagai asumsi satu semester sama dengan satu level permainan game.

Game yang akan dibuat oleh penulis adalah game bergenre side scrolling atau biasa disebut juga Platformer yang memiliki jalan cerita, yang mengkondisikan karakter untuk berjalan berpetualang demi mencapai tujuan sesuai yang ada di gameplay, cerita yang diangkat penulis pada game ini adalah tentang perjalanan siswa lulusan SMA sederajat yang ingin berkuliah di Informatika Universitas Mulawarman [10][11], dan di game ini akan memberikan pengetahuan tentang apa saja yang diperlukan oleh mahasiswa baru untuk masuk ke jenjang perkuliahan seperti contohnya adalah syarat-syarat daftar ulang yang diperlukan, perjalanan kuliah per semester hingga kemudian lulus pada akhir game. Alasan dibuatnya game ini adalah agar mahasiswa baru bisa mengetahui apa saja yang dibutuhkan untuk memulai perkuliahan dan apa saja yang diperlukan selama perkuliahan hingga bisa lulus ataupun permasalahan apa saja yang bisa terjadi di kampus selama berkuliah.

\section{Metode}

Bagian ini akan membahas tentang Analisa dan konsep pembuatan game ini secara umum.

\subsection{Keterangan Umum}

Game ini meliputi berbagai macam faktor penting dalam pembuatannya yaitu :

1. Scoring, skor dalam game ini adalah $75 \%$ bedasar pada waktu dan $25 \%$ dari pertanyaan

2. Timer, Timer dalam game memiliki 4 penilaian yang terbagi menjadi dibawah 60 detik, diatas 60 detik namun dibawah 75 detik, diatas 75 detik namun dibawah 90 detik, dan diatas 90 detik.

3. Materi dan pertanyaan, terdapat 5 pertanyaan dalam game ini pada setiap semester (level) yang memiliki bobot $25 \%$ dari nilai yang akan didapatkan.

4. Levelling, terdiri dari 7 level sesuai dengan perkuliahan.

\subsection{Skenario Game OTW Sarjana}

Setelah lulus Sekolah Mengenah Atas, siswa bernama Joni ingin melanjutkan pendidikannya ke tingkat perkuliahan, dia pun diterima di Program Studi Informatika Universitas Mulawarman, Joni pun sangat senang karena bisa diterima di program studi tersebut. Akhirnya Joni pun pergi di jurusan Informatika Universitas Mulawarman Samarinda, Joni pun melengkapi segala hal yang diperlukan untuk menjadi mahasiswa di kampus tersebut dari mulai pendaftaran ulang, pengisian KRS dan pengambilan foto dengan almamater, Joni lakukan semuanya di kampus tersebut setelah segala sesuatunya selesai, Joni pun akhirnya bisa belajar mata kuliah yang telah diambilnya pada saat pengisian KRS.

Joni pun memulai perkuliahan dari semester 1 hingga semester 7, di setiap semesternya Joni diharuskan berlari melewati segala rintangan yang ada dengan target waktu lebih cepat dari 60 detik dan bukan hanya itu saja, Joni pun diharuskan memperhatikan setiap materi yang diberikan pada setiap semester/level nya sehingga pada akhir level, Joni bisa menjawab pertanyaan yang diberikan dengan tepat dan mendapatkan Nilai IP yang bagus agar bisa melanjutkan ke semester selanjutnya dan begitu seterusnya.

Jika nilai Joni bagus atau diatas IP 2.0 maka Joni bisa melanjutkan ke semester selanjutnya jika tidak, maka di haruskan mengulang. Setelah Joni berada pada semester enam, Joni pun harus mengikuti kegiatan KKN dan PKL yang diselenggarakan oleh Universitas Mulawarman, dalam kegiatan tersebut Joni diharuskan membantu masyarakat yang ada pada sebuah desa dan pada saat PKL Joni harus membantu karyawan yang ada di perusahaan, jika Joni bisa menyelesaikan segala sesuatunya dengan baik maka Joni bisa lulus.

Pada semester akhir Joni dihadapkan dengan skripsi, oleh karena itu dia diharuskan mengejar dosen dan menjawab pertanyaan yang berkaitan dengan seminar proposal, hasil dan pendadaran hingga akhirnya bisa lulus/wisuda. 
Jurnal Sistem Informasi dan Sistem Komputer, Vol.6, No.2, Juli 2021

ISSN: 2715-906X (Online)

d $\circ$ i $10.51717 /$ simkom.v6i2.56

\subsection{Penerapan Metode Forward Chaining}

Forward chaining disebut juga suatu penalaran yang dimulai dari bawah ke atas karena penalaran berdasarkan fakta pada level bawah menuju kesimpulan pada level atas yang didasari dengan fakta [12]. Teknik penelusuran yang diawali dengan fakta yang sudah diketahui, setelah itu mencocokkan fakta-fakta dengan IF tersebut dari aturan IF-THEN, apabila ada fakta yang cocok dengan IF, maka aturan tersebut dieksekusi [13]. Bila sebuah aturan dieksekusi maka ada fakta yang baru (THEN) dimasukkan kedalam database [14][15]. Metode yang digunakan pada game ini adalah metode forward chaining yang digunakan pada saat perhitungan nilai akhirnya di tiap level [16].

Metode Forward Chaining digunakan pada setiap akhir semester (level) untuk menentukan nilai dan pilihan, apakah nilai tersebut cukup untuk melanjutkan ke semester (level) selanjutnya atau tidak, dan jika tidak maka mengharuskan pemain untuk mengulang semester (level) tersebut. Aturan atau fakta yang digunakan pada perhitungan nilai ini adalah aturan pertama yaitu waktu penyelesaian pada setiap semesternya (level) yang akan ditambahkan dengan jumlah pertanyaan terjawab pada akhir semester (level) untuk menentukan nilai [17].

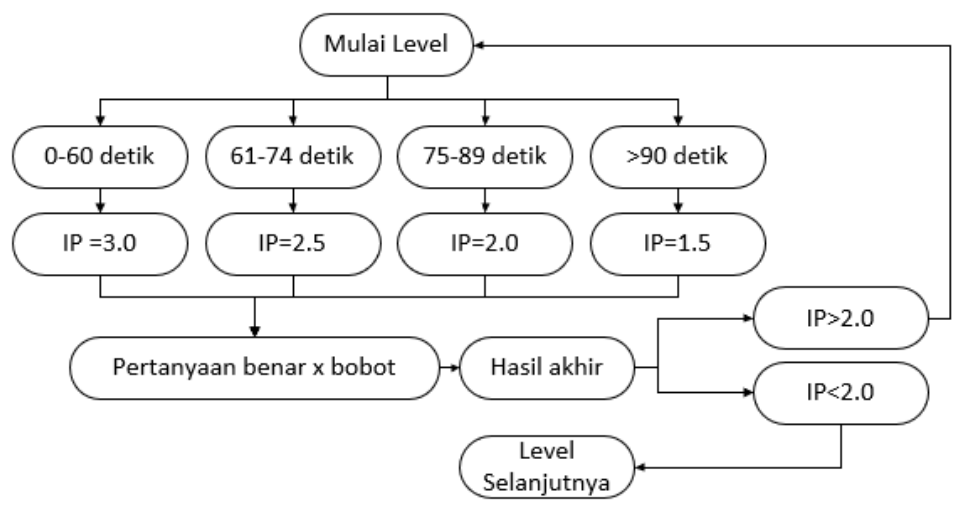

Gambar 1. Alur level permainan

\section{Hasil dan Pembahasan}

\subsection{Hasil}

Bagian ini meliputi hasil, implementasi dan pengujian game.

A. Tujuan Game

1. Mendapat IP Semester diatas $2.0=$ Naik Semester

2. Mendapat IP Semester dibawah $2.0=$ Ulang Semester

3. LULUS Kuliah

B. Peraturan Game

1. Pemain bersifat Single Player.

2. Pemain diharuskan menggunakan keyboard (arah panah) untuk menjalankan karakter di dalam permainan.

3. Pemain bisa menggunakan mouse/touchpad untuk memilih pilihan menu yang ada.

4. Dalam setiap level/semester pemain akan disajikan materi pernyataan yang berbeda-beda yang pada akhirnya harus dijawab diakhir level/semester.

C. Desain Musik Dan Suara

1. Ketika Mulai Game hingga akhir Game : Solomon Allen - RPG Title Screen Music Pack 02 Forward! The Advent of Birth to Adventure Start With You!

2. Ketika karakter melompat : platformer_jump/jump_02

3. Ketika karakter bertemu dosen killer : Irrational Machines - RPG Title Screen Music Pack 01 Title Screen 
Jurnal Sistem Informasi dan Sistem Komputer, Vol.6, No.2, Juli 2021

ISSN: 2715-906X (Online)

d $\circ$ 10.51717/simkom.v6i2.56

D. Tombol Dalam Game

Tombol yang digunakan pada saat bermain game ini adalah sebagai berikut:

Tabel 1. Tombol Yang Digunakan

\begin{tabular}{lll}
\hline Perintah & \multicolumn{1}{c}{ Tombol } & \multicolumn{1}{c}{ Fungsi } \\
\hline Jalan Ke-Kanan & "Panah Kanan" & $\begin{array}{l}\text { Gerakan dasar Menggerakkan } \\
\text { karakter ke kanan }\end{array}$ \\
Jalan Ke-Kiri & "Panah Kiri" & $\begin{array}{l}\text { Gerakan dasar Menggerakkan } \\
\text { karakter ke kiri }\end{array}$ \\
Melompat & "Panah Atas" & $\begin{array}{l}\text { Gerakan dasar Menggerakkan } \\
\text { karakter untuk melompat }\end{array}$ \\
Operasi dalam Game & "Klik Kiri Mouse" & $\begin{array}{l}\text { Klik kiri mouse berguna untuk } \\
\text { banyak operasi diantaranya } \\
\text { adalah memilih jawaban, } \\
\text { mengulang level, melanjutkan }\end{array}$ \\
\hline
\end{tabular}

E. Item Beserta Simbol Di Dalam Game

Item yang terdapat di dalam game ini beserta dengan simbolnya sebagai berikut:

Tabel 2. Item Dalam Game

Jika karakter melompat hingga terkena item ini maka
akan membuat karakter berpindah ke lantai dua.


Jurnal Sistem Informasi dan Sistem Komputer, Vol.6, No.2, Juli 2021

ISSN: 2715-906X (Online)

d $10.51717 /$ simkom.v6i2.56

Bu Islamiyah

Ketua Jurusan

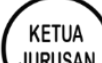

JURUSAN

Koordinator Prodi

Teknik

Informatika

Data Krs

Susu

Kopi

Minuman Energi

Kaki

Quiz

UAS

Materi

Kayu

Beras Bulog
Jika karakter melompat hingga terkena item ini maka akan membuat karakter mendapatkan TTD Ibu Islamiyah di KRS.

Jika karakter melompat hingga terkena item ini maka akan membuat karakter mendapatkan TTD Pak Edy Budiman di KRS.

Jika karakter melompat hingga terkena item ini maka akan membuat karakter mendapatkan TTD Ibu Masna di KRS

Jika mengklik item ini maka akan masuk menampilkan KRS sesuai dengan TTD yang didapatkan.

Jika karakter bersentuhan dengan item ini maka akan menambah kecepatan berlari selama 4 detik.

Jika karakter bersentuhan dengan item ini maka akan mengurangi kecepatan berlari selama 4 detik.

Jika karakter bersentuhan dengan item ini maka akan membuat karakter menjadi besar selama 4 detik.

Jika karakter bersentuhan dengan item ini maka mengaktifkan "double jump".

Simulasi dari quiz pekuliahan di dalam game ini, jika terkena maka akan menambah waktu 2 detik yang akan merugikan pemain.

Simulasi dari UAS perkuliahan di dalam game ini, jika terkena maka akan menambah waktu 3 detik.

Item yang akan menunjukkan materi pada layar pemain pada saat karakter pemain menyentuhnya.

Item ini bisa berguna untuk menjadi pijakan pemain menuju tempat yang lebih tinggi.

Simulasi dari KKN ini adalah berupa item beras bulog yang harus diberikan kepada karakter berbaju merah guna melanjutkan perjalanan, ketika mengambil akan mengurangi waktu 5 detik. 
Jurnal Sistem Informasi dan Sistem Komputer, Vol.6, No.2, Juli 2021

ISSN: $2715-906 \mathrm{X}$ (Online)

d $\circ$ 10.51717/simkom.v6i2.56

Project PKL

Simulasi dari PKL ini adalah berupa item Project PKL

$\underset{P \mathrm{PRL}}{\mathrm{PROECT}}$ yang harus diberikan kepada karakter berbaju merah guna melanjutkan perjalanan, ketika mengambil akan mengurangi waktu 5 detik.

SEMPRO

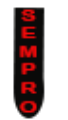

Simulasi dari Seminar Proposal di dalam game ini, jika terkena maka akan menambah waktu 2 detik.

Revisi

Simulasi revisi dalam game ini, jika terkena akan menambah waktu 2 detik.

SEMHAS

Simulasi dari Seminar Hasil di dalam game ini, jika terkena maka akan menambah waktu 3 detik.

PENDADARAN

Simulasi dari pendadaran di dalam game ini, jika terkena maka akan menambah waktu 4 detik.

F. Implementasi Game

Implementasi dari desain dan konsep game sebagai berikut:

1. Desain Karakter

Karakter dalam game ini ada dua yaitu karakter utama dan karakter dosen killer, Seluruh proses pembuatan karakter menggunakan software Adobe Photoshop CS6, berikut adalah desain karakter utama dan karakter dosen killer:

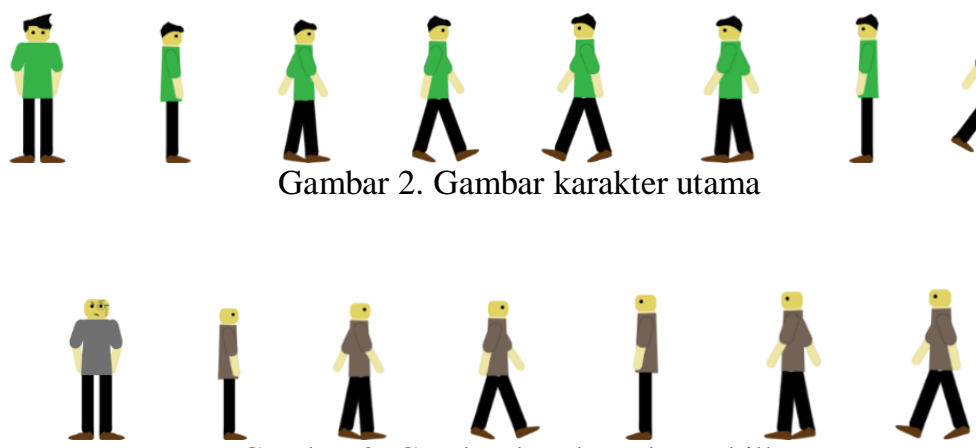

Gambar 3. Gambar karakter dosen killer

2. Desain Tampilan Layar Pengguna

Desain tampilan layar game "OTW SARJANA" dari mulai menu utama hingga akhir semester, seluruh proses menggunakan software Adobe Photoshop CS6, berikut adalah tampilannya:
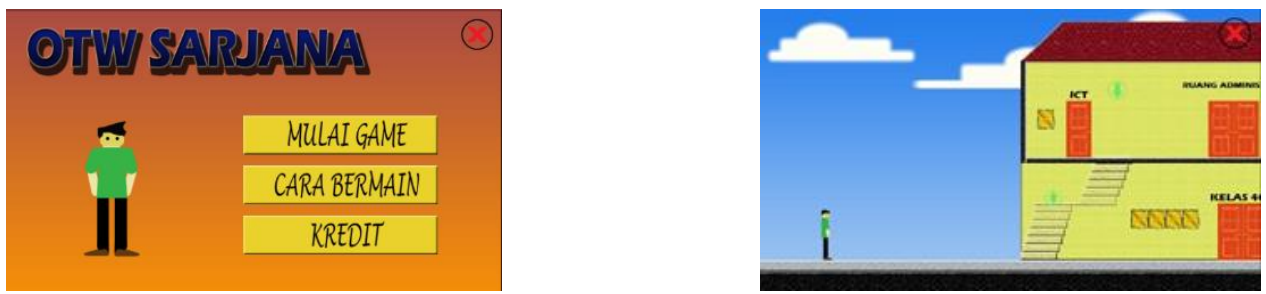

Gambar 4. Tampilan Menu Awal Game

Gambar 5. Tampilan Kampus/Beranda game 
Jurnal Sistem Informasi dan Sistem Komputer, Vol.6, No.2, Juli 2021

ISSN: 2715-906X (Online)

d $\circ$ 10.51717/simkom.v6i2.56

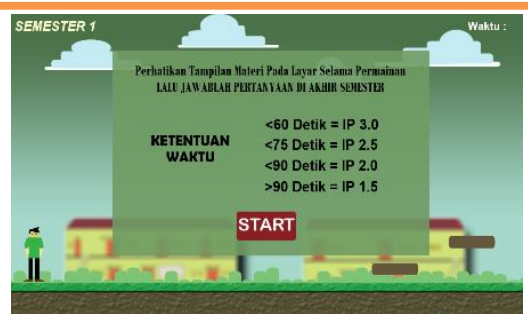

Gambar 6. Tampilan Awal Semester

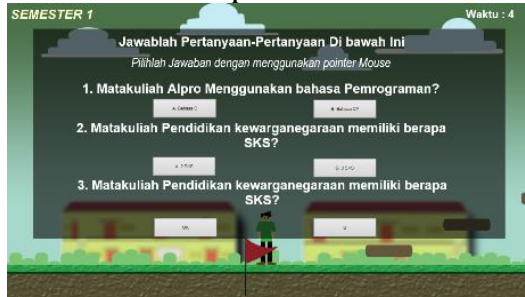

Gambar 8. Pertanyaan Akhir Semester

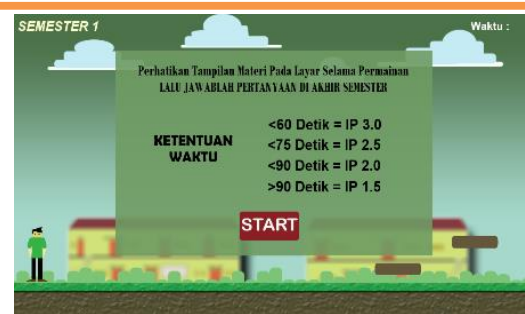

Gambar 7. Tampilan dalam semester game

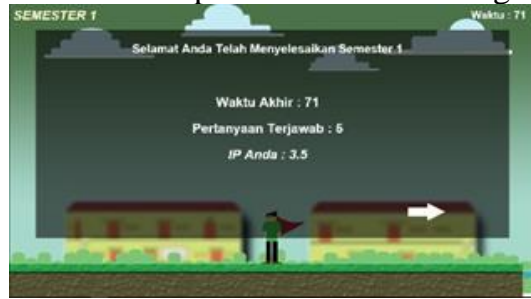

Gambar 9. Tampilan Hasil Akhir Semester

\subsection{Pembahasan}

A. Penerapan Dan Pengujian

Pengujian Metode Forward Chaining dan pengujian permainan dapat dilihat pada Tabel 3.

Tabel 3. Penerapan dan Pengujian Metode Forward Chaining

\begin{tabular}{cccccc}
\hline No & Waktu & Pertanyaan Terjawab & IP & Lulus/Ulang & Keterangan \\
\hline 1 & $<60$ Detik & 5 & 4.0 & Lulus & Berhasil \\
2 & $<60$ Detik & 4 & 3.8 & Lulus & Berhasil \\
3 & $<60$ Detik & 3 & 3.6 & Lulus & Berhasil \\
4 & $<60$ Detik & 2 & 3.4 & Lulus & Berhasil \\
5 & $<60$ Detik & 1 & 3.4 & Lulus & Berhasil \\
\hline
\end{tabular}

Pengujian Metode berhasil 100\% dan digunakan pada 7 semester dalam game ini, pengujian yang dilakukan selanjutnya yaitu dengan 4 orang sample game tester dengan hasil yang ditunjukkan pada Tabel 4.

Tabel 4. Pengujian permainan

\begin{tabular}{ccccccccc}
\hline \multirow{2}{*}{$\begin{array}{c}\text { Jumlah } \\
\text { Sample }\end{array}$} & Yang diuji & \multicolumn{7}{c}{ Rata-rata } \\
\cline { 3 - 8 } 4 orang & $\begin{array}{c}\text { Waktu } \\
\text { (Menit) }\end{array}$ & 122.7 & 89.93 & 88 & 103 & 84.5 & 90.17 & 127.5 \\
& $\begin{array}{c}\text { Jumlah } \\
\text { jawaban } \\
\text { benar }\end{array}$ & 4 & 4.3 & 2.7 & 2.3 & 3.7 & 2.83 & 4.67 \\
& IP & 2.3 & 2.667 & 2.7 & 2.3 & 2.23 & 2.483 & 2.433 \\
\hline
\end{tabular}

Kesimpulan hasil pengujian yang dilakukan menunjukkan rata-rata empat orang sampel tersebut, mendapatkan hasil yang cukup rendah pada setiap semesternya, dikarenakan waktu penyelesaian yang cukup lama, namun rata-rata pertanyaan yang terjawab yang cukup baik menyebabkan empat orang sampel tersebut selalu lolos ke semester selanjutnya. 
Jurnal Sistem Informasi dan Sistem Komputer, Vol.6, No.2, Juli 2021

ISSN: 2715-906X (Online)

doi) $10.51717 /$ simkom.v6i2.56

\section{Kesimpulan dan Saran}

Berdasarkan hasil perancangan ini, dapat disimpulkan tahapan yang diimplementasikan dalam pembuatan game ini adalah konsep, desain, pembuatan game dan pengujian. Forward Chaining merupakan metode yang dapat diterapkan dan dapat digunakan pada game dua dimensi bergenre side scrolling. Walaupun dalam gameplay dan testing masih dijumpai kendala dalam adaptasi permainan oleh user. Tetapi dalam rata-rata waktu dan skor bermain bisa di telaah bahwa user bermain dengan kemampuan apa adanya yang mereka bisa berikan.

\section{Daftar Pustaka}

[1] M. B. Firdaus, E. Budiman, M. F. Anshori, J. Teknologi, and U. Mulawarman, "Evaluasi Skema Panduan Game Berbasis Motion Graphic Animation Pada Esports Bergenre Multiplayer Online Battle Arena," JURTI Univ. Mulawarman, vol. 4, no. 1, p. 36, 2020.

[2] J. M. Patricio, M. C. Costa, and A. Manso, "A Gamified Mobile Augmented Reality System for the Teaching of Astronomical Concepts," no. June, pp. 1-5, 2019, doi: 10.23919/cisti.2019.8760658.

[3] H. Sugiarto, "Penerapan Multimedia Development Life Cycle Pada Aplikasi Pengenalan Abjad Dan Angka," IJCIT (Indonesian J. Comput. Inf. Technol., vol. Vol.3 No.1, no. 1, pp. 26-31, 2018.

[4] Bagas Kurniawan, Ade Ajie Ferizal, and Iskandar, "Rancang Bangun Game Badex Hurdle Berbasis Multimedia Menggunakan Macromedia Flash 8," TEKNOSAINS J. Sains, Teknol. dan Inform., vol. 8, no. 1, pp. 1-9, 2021, doi: 10.37373/tekno.v8i1.71.

[5] P. A. Rauschnabel, A. Rossmann, and M. C. tom Dieck, "An adoption framework for mobile augmented reality games: The case of Pokémon Go," Comput. Human Behav., vol. 76, pp. 276-286, 2017, doi: 10.1016/j.chb.2017.07.030.

[6] A. Rokhmawati, G. Radityo Kusumo, I. Dwi Wahyoho, and R. Irawati, "Ultranus: A Novel Indonesian Cultural Game Using Artificial Intelligence," Proc. - 2018 Int. Semin. Appl. Technol. Inf. Commun. Creat. Technol. Hum. Life, iSemantic 2018, pp. 361-366, 2018, doi: 10.1109/ISEMANTIC.2018.8549744.

[7] J. Zakharia, I. Fenriana, and E. D. Kusuma, "Aplikasi Pengenalan Suara Hewan Pada TK Pelangi Dengan Metode Forward Chaining," J. ALGOR, vol. 1, no. 2, 2020.

[8] K. Schwaber and J. Sutherland, "The Scrum Guide: The Definitive The Rules of the Game," Scrum.Org and ScrumInc, 2017, doi: 10.1053/j.jrn.2009.08.012.

[9] F. Ahmed, M. Zia, H. Mahmood, and S. Al Kobaisi, "Open Source Computer Game Application: An Empirical Analysis of Quality Concerns," Entertain. Comput., 2017, doi: 10.1016/j.entcom.2017.04.001.

[10] A. Tejawati, E. K. Pradana, M. B. Firdaus, F. Suandi, L. Lathifah, and M. K. Anam, "Pengembangan Video Dokumenter 'Wanita Dan Informatika' Di Lingkungan Fkti Universitas Mulawarman," J. Inform. dan Rekayasa Elektron., vol. 2, no. 2, p. 72, 2019, doi: 10.36595/jire.v2i2.121.

[11] M. B. Firdaus, N. Puspitasari, E. Budiman, J. A. Widians, and N. Bayti, "Analysis of the effect of quality mulawarman university language center websites on user satisfaction using the webqual 4.0 method," Proc. ICAITI 2019 - 2nd Int. Conf. Appl. Inf. Technol. Innov. Explor. Futur. Technol. Appl. Inf. Technol. Innov., pp. 126-132, 2019, doi: 10.1109/ICAITI48442.2019.8982143. 
Jurnal Sistem Informasi dan Sistem Komputer, Vol.6, No.2, Juli 2021

ISSN: 2715-906X (Online)

doi) $10.51717 /$ simkom.v6i2.56

[12] A. F. Hadi, "Analisa Ketangkapan Daya Ingat Anak Dengan Menggunakan Game Edukasi Non Player Character 'Ani!' Berbasis Android," UPI YPTK J. PSYCHE, vol. 11, no. 1, pp. 55-65, 2018.

[13] Sugianto and veicy A. Ansyah, "Implementasi Metode Forward Chaining Untuk Mengelompokkan Objek Berdekatan Pada Same Game," J. Manaj. Inform. Komputerisasi Akunt., vol. 11, no. May, pp. 14-21, 2018.

[14] Alpin and S. Syofian, "Implementasi Forward Chaining Pada Game Interaktif 'Bersihkan Kotaku' dengan Pendekatan Gamification Berbasis Android," J. SAINS Teknol., vol. X, no. 2, 2020.

[15] F. Fujiati, F. Nasari, S. L. Rahayu, and A. Sanjaya, "Educational Game as a Learning Media Using DGBL and Forward Chaining Methods," 2018 6th Int. Conf. Cyber IT Serv. Manag. CITSM 2018, no. Citsm, pp. 1-4, 2019, doi: 10.1109/CITSM.2018.8674316.

[16] M. Mujib, A. Khafid, and S. Sumarlinda, "EasyChair Preprint Expert System Detecting Symptoms Of Game Addiction With The Forward Chaining Method And Certainty Factor," 2nd Int. Confrence Heal. Sci. Technol., 2021.

[17] M. B. Firdaus, E. Budiman, joan angelina Widians, novel maringan Sinaga, S. Fadli, and F. Alameka, "Augmented Reality for Office and Basic Programming Laboratory Peripheral," 2018 2nd East Indones. Conf. Comput. Inf. Technol., vol. 2, no. 2, pp. 4145, 2018. 